\title{
Investor Trading Behavior Around the Time of Geopolitical Risk Events: Evidence from South Korea
}

\author{
Young Han (Andy) KIM* \\ Hosung JUNG**
}

The views expressed herein are those of the author and do not necessarily reflect the official views of The Bank of Korea. When reporting or citing it, the author's name should always be stated explicitly.

\footnotetext{
* Assistant Professor of Finance, Nanyang Business School, NTU, Singapore, yhkim@ntu.edu.sg, 656790-4639, 50 Nanyang Avenue, S3-B1A-16, Singapore, 639798.

** Senior Economist, Financial \& Monetary Economics Team, Economic Research Institute, the Bank of Korea. hschung@bok.or.kr, 82-2-759-5308, 39 Namdaemun-Ro, Jung-Gu, Seoul, 100-794, South Korea.
}

The authors thank the seminar participants at City University of Hong Kong, Hong Kong Polytech University, the Economic Research Institute of the Bank of Korea, and Nanyang Business School. Special thanks go to Steve Dimmock and Dough Rolph, who have given us detailed comments and suggestions for the paper. We also thank Agnes Chen, Woon Gyu Choi, Gunter Dufey, Huasheng Gao, Qianqian Huang, Byoung Hyoun Hwang, Byoung Uk Kang, Jun-Koo Kang, Hyun Seung Na, Chang Hwan Sung, Giorgio Valente, Junbo Wang, Lei Zhang, and Yong Zhang for insightful comments. We also thank Young Jae Choi, Kyung Hoon Chung, Suh Yoon Jin, Nae Young Kang, Daseul Lee, Jung Eun Lee, and Hyeonjeong Ko for their excellent research assistance. All errors are our own.

The views expressed in this paper are those of the authors and do not necessarily represent those of the Bank of Korea. 


\section{Contents}

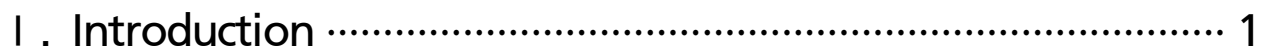

II . Literature Review …........................................................... 6

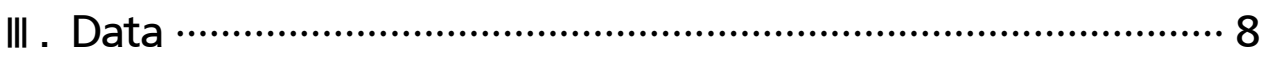

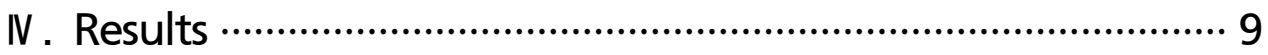

1. Daily event study using KOSPI index returns …………………….... 9

2. Daily event study using market index returns of the US …….... 14

3. Analysis of stock level responses in SK ………............................. 15

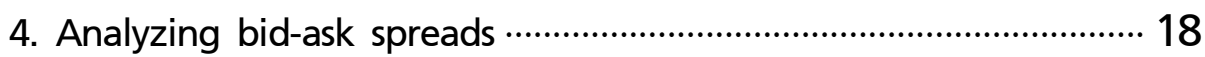

5. Daily abnormal volume event study ……………........................ 20

6. Volumes of short selling around the time of NK events ….........22

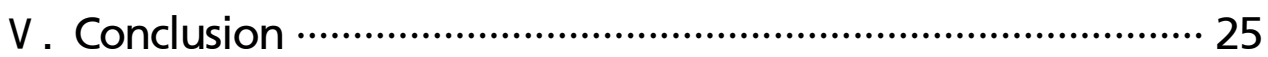

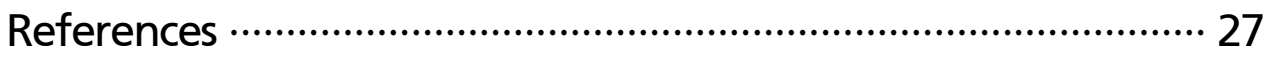

Appendix 


\section{Investor Trading Behavior Around the Time of Geopolitical Risk Events: Evidence from South Korea}

How do investors respond to geopolitical risk events? The South Korean stock market gives an interesting testing ground because the nuclear weapons testing and military aggressions by its belligerent neighboring country, North Korea, are exogenous. Moreover, as North Korea has transitioned from a state without nuclear weapons to one with substantial nuclear capabilities, investors have revised their beliefs about the level of geopolitical risk with each weapons test. Using Korean microstructure data from 1999 to 2012, we find a permanent negative abnormal return of $-1.6 \%$ in the South Korean market (and $-0.88 \%$ for the US market) for nuclear weapons testing, but do not find significant return for military attacks. Bid-ask spread analysis indicates significant increases in information asymmetry among investors before these events. Moreover, we find a significant spike in abnormal short selling volume before the events.

Keywords: North Korea; Individual investors; Institutional investors; Foreign investors; Short selling; Media sentiment; China, Geographical distance; Geopolitics, Bid-ask spread; Liquidity

JEL Classification: D74, G02, G14, G15, P16 


\section{Introduction}

Geopolitical security is one of the bare necessities to have a well-functioning financial market. Even the most sophisticated stock markets like the NYSE and NASDAQ had to delay their openings on the day of the 9/11 terrorist attacks, and remained closed for a week. In this paper, we study the investor behavior surrounding geopolitical risk events. Though many researchers find significant investor responses to political events in different international settings, one of the issues is that a shock in geopolitics may be a function of the financial markets of the countries involved, especially due to the globalized capital markets. South Korea (SK, hereafter) gives us an interesting testing ground in this sense, because its long-time source of menace has been North Korea (NK, hereafter), its cousin brother country - nicknamed the "hermit kingdom" - ruled by a communist dictatorship dynasty without a capital market for more than half a century.

NK has been drawing much attention from the world for a long time with its belligerent rhetoric against the US and SK.1) The reckless brinkmanship of NKand accordingly, the tension level - has grown worse since the late 1990s due to the country's constant endeavors to establish the capability of producing nuclear weapons and long range missiles (LRMs, hereafter), to secure its regime from both outside and inside forces. The uncertainty surrounding the Korean peninsula has been heightening since the death of "Dear Leader," Kim Jong-Il in late 2011. With the succession of the new dictator, Kim Jong Un, who is barely thirty years old, NK escalated tensions in the region by proclaiming that it would attack SK and even the US with its newly tested LRMs, carrying its own nuclear warheads. As a result, in the spring of 2013, some heavy weight multinationals operating in SK, such as General Motors, and some foreign embassies, began to draw up serious contingency plans for their employees and compatriots living in SK (Choe, 2013). The New York

1) Despite the fact that SK is the 15th largest country in the world in terms of GDP (World Bank: http:/ / data.worldbank.org/data-catalog/GDP-ranking-table), and despite the fact that the GNI of NK is only $2.6 \%$ of that of SK (Statistics Korea, http://stat.mw.go.kr/front/statData/publicationView.jsp?menuId= $44 \&$ bbsSeq=10\&nttSeq=20442\&searchKey=\&searchWord=\&nPage=1), NK has been drawing much more attention from the world, as can be seen in our comparison using the Google Search Volume Index in Appendix A. 
Times (2013) quoted Mr. Coyner of the American Chamber of Commerce in SK: “[NK's threat] is a very interesting, sophisticated economic attack on SK," because the nuclear threat of NK negatively affects SK's stock market and business.

What is the potential impact of NK's nuclear menace on the world economy? In fact, the combined size of the economies of the countries around NK is now greater than that of the economy of the European Union. Based on IMF data in 2012, 24 percent of world GDP is concentrated in the region surrounding the Korean peninsula: China (11.4\%), Japan (8.3\%), Russia $(2.8 \%)$, and SK $(1.6 \%)$. In comparison, the GDP of the European Union accounts for $23 \%$ of that of the world. Therefore, a potential (nuclear) war on the Korean peninsula could not only cause unprecedented human casualties but also devastate the world economy on a massive scale.2)

Not only the nuclear threat but also the possibility of a sudden implosion of the NK regime with its nuclear weapons is a source of risk, due to the high likelihood of sale of these weapons to terrorists or unwanted states by potential warlords, not to speak of the potential influx of millions of refugees into China. Ian Bremmer, head of the geopolitical risk consulting company the Eurasia Group, pointed out at the Davos World Economic Forum in 2014 that an implosion of NK would be a very serious problem in East Asia, because Kim Jung Un "has not given any confidence to believe that he knows how to run a (nuclear) totalitarian country (Wiesenthal, 2014)." In addition, recently, Falletti (2014) pointed out that the obsolescence of NK's nuclear power plants poses even more serious environmental risks than that from "Chernobyl" upon neighboring countries.

2) There is one more imminent risk factor near the Korean peninsula. China has been the closest and the most powerful ally of NK, and it is almost the only effective communication channel to the NK leaders. In an untabulated event study, we find that the SK stock market index increases by $1.69 \%$ ( $\mathrm{t}$-stat=1.66, $\mathrm{N}=14$, event window: [0,2] trading days) when China works as an intermediary in multiparty talks to solve problems on the Korean peninsula. Japan and SK have been important strategic allies to the US since Korean War. Recently, the geopolitical tensions between China and Japan drastically increased due to their territorial disputes over Diaoyudao (or the Senkaku Islands: see map in Appendix B), to the point of the Japanese Prime Minister addressing it as "a similar situation to Britain and Germany before World War I" (Rachman, 2014). Therefore, a war on the Korean peninsula could easily spread to become a much larger scale military conflict between China and Japan. A recent report by the Center for Risk Institute of Cambridge University argues that a potential war between China and Japan would drag down the world economy into a recession of more than four years (Wallace, Hartley, Bowman, Coburn, and Ruffle, 2013). 
As financial economists, we address the question of how much and how fast investors respond to events of geopolitical risk, and who responds first or even short sells in advance. North Korean military threats have been "credible," because the country's track record of military aggression includes the full-scale war in 1950 that involved major superpowers such as the US, the Soviet Union, and China, the assassination of the SK First Lady in 1974, the killing of 17 SK cabinet members during a diplomatic visit to Myanmar in 1983, and the shelling of Yeonpyeong Island in 2010. Additionally, the unpredictable nature of North Korean attacks enables us to identify the exogenous shock in geopolitical risks.

Some readers may argue that the long history of stand-off between NK and SK with the presence of the US forces on South Korean soil indicates that NK would not wage a full-scale war. As has been widely reported (McLeod, 2013), most South Koreans take the military threat of NK as "business as usual." Thus, one might argue that the military attacks of NK do not imply any change in the level of geopolitical risk. They might be just non-informative attention drawing events, generating overreactions by unsophisticated investors or unfamiliar investors trading in SK. Taking this one step further, one might argue that the geopolitical risk attributable to NK must have been already priced in the SK stock market in the name of the "Korea Discount" (The Wall Street Journal, 2010). Consequently, any events instigated by NK will not trigger any permanent stock price changes. The empirical evidence in the literature is mixed. Nam (2002) documents insignificant price responses to NK attacks, but Ahn, Chay and, Jeon (2010), Gerlach and Yook (2013), and Lee (2006) find negative price responses.

While the aforementioned overreaction story should be well taken, we have a strategy to identify the change in the level of geopolitical risk. Having an enemy with nuclear weapons (nukes, hereafter) and LRMs is a totally different state of nature in terms of geopolitical risk compared to having an enemy without them. During our sample period, NK has gradually transitioned from a country without nuclear weapons to a country with significant capabilities in both nukes and LRMs (Lee, 2013; and UPI, 2013). Such weapons development programs might have been met with pre-emptive US airstrikes - as in Iraq or Libya - or with very serious military diplomatic reactions from the neighboring countries. However, the program of NK 
was not. One of the reasons may be the unique situation of SK as a virtual hostage. In SK, almost half of the population (50 million) and about the same proportion of its industrial facilities are concentrated in the metropolitan Seoul area, which is within easy range of the guns of NK (see Appendix B).

As a result, NK has been developing and testing nuclear weapons and long-range missiles over the last decade, accompanied by a series of diplomatic games. Thus, both SK and the US have been going through gradual changes in the state of nature. Our hypothesis is that the stock price responses to the nuclear testing by NK have been significantly negative and permanent. In contrast, however, we hypothesize that the other acts of military aggression by NK have not resulted in permanent decreases in stock prices, because they have not given any updates in beliefs about the level of geopolitical risk.

Using Korean stock market data and the hand-collected data on nuclear-/LRMrelated events and military aggression over the 1999 2012 period, we find supporting evidence for our hypotheses. The series of tests of nuclear weapons and LRMs has resulted in a permanent and significant decrease in the stock market (KOSPI) index of $-1.59 \%$. This abnormal return translates into USD 17.6 billion or $1.56 \%$ of SK GDP as of the end of 2012.3) Interestingly, the magnitude of the price response has diminished over time, suggesting that most of investors' learning about NK nuclear capabilities took place until 2009. Since the US is NK's proclaimed major adversary, we also investigate the stock market response in the US and find a statistically significant abnormal return of $-0.88 \%$ over a $[-1,1]$ days window. The price response in the US became more negative after NK began testing longer range missiles. In contrast to all of this, the investor response to major military attacks of NK is insignificant. This reconciles the recent puzzle in the literature. Our study reveals that nuclear testing has significant information content about the gradual change in the state of situation of dealing with a counterparty that has a nuclear capability.

If some investors are better informed than others about NK's forthcoming actions, the asymmetric information would widen the bid-ask spread. Specifically, some

3) According to the World Bank, SK GDP was USD 1,130 billion in 2012. The aggregate market cap of Korean stocks was meanwhile KRW 1,178 trillion as of 12/31/2012, which with a KRW/USD exchange rate of $1,062.87$ translates to USD 1,108 billion. 
investors might have better access to information about NK, possibly through various international intelligence networks inside and outside of SK. Unlike Gerlach and Yook (2014), we are open to the possibility that SK is as foreign as any other country with respect to insider information on NK (as discussed in Section 2). We find that the bid-ask spread increases significantly before NK military actions. One might argue that this increase in bid-ask spread could also be explained by the distraction (Hirshleifer, Lim, Teoh, 2010) that NK causes to the SK market, as traders could be significantly disturbed by the geopolitical news or anticipation of the events. If so, however, the liquidity in the market should also dry up and the trading volume decrease significantly. However, we do not find supporting evidence of this.

When some investors are better informed about forthcoming NK military aggression or nuclear testing, they could profit from their informational advantages by short selling stocks. And since the SK microstructure data identifies short sales, we study the volumes of abnormal short selling surrounding NK nuclear weapons/ LRM testing and acts of military aggression. Since the nationalities of foreign investors are also identified (247 of them), we group them into foreigners from countries that have diplomatic relations with NK (147 countries) and those that do not (100 countries). We find that the volumes of abnormal short selling by non-resident foreign institutions from countries with diplomatic relations with NK, as well as those by domestic investors, increase significantly even five trading days before the events in question. In contrast, we find no significant abnormal short selling from non-resident foreign institutions of countries without diplomatic relations with NK.

The rest of this paper is organized as follows. In section 2 we briefly review the literature. Section 3 then describes the collection of data, and the results are reported in Section 4. We conclude in Section 5. In technical appendix, we show our microstructure event study results to see the speed of real time investor response to geopolitical risk events and the trading behavior of individual investors at the minute of breakout of surprise attacks. 


\section{Literature Review}

Poteshman (2006) is comparable to our study in that both papers attempt to look forensically at the behaviors of investors that have information advantages before geopolitical events. He finds abnormally high long positions of put options for the related airline stocks on the day before the 9/11 terrorist attack, a piece of evidence suggesting that the terrorists and their associates were profiting from their advance knowledge of the attack. Because we do not have option trading data, we look at the volumes of abnormal short selling by the different nationalities of traders and find supporting evidence for potential political insider trading.

Gerlach and Yook (2014) [GY, hereafter] comes close to our paper in that both study the stock market impacts of NK aggression. However, our paper differs in several important dimensions. First, GY is concerned with testing whether foreign investors destabilize the SK stock market at around the time of NK military aggression, in the vein of Choe, Kho, and Stulz (1999). Our interest is, in contrast, identifying the economic magnitudes of the impacts of change in the geopolitical risk level, specifically associated with NK's testing of nuclear weapons and LRMs. While GY treat both nuclear weapons testing and military aggression as the same group of events, we classify them into different groups because the former causes significant belief revisions in the perceived level of geopolitical risk while the latter does not.

Second, we study the information asymmetry among investors and investigate their short selling behaviors before surprise attacks. We investigate the potential information leakages before events that may drive some investors to move ahead of their occurrence.

Third, GY assume that domestic investors in SK have better information about NK than foreigners, which encourages them to build arguments about their contribution to the literature on home bias and international diversification. We, however, do not take this assumption as granted. Due to the secretive nature of NK, SK might be as foreign as any other country in terms of its access to information on NK, especially about its nuclear weapons program. In our process of collecting event dates concerning $\mathrm{NK}$, we have realized that it is US websites that provide the largest amount of information about NK, not those of SK. Kim (2014) finds that the tone of the English 
news published outside of SK has better predictive power about NK's belligerent action choices than that of the English news media inside SK. Though parsing of Korean language media inside SK should also be considered to make the argument complete, the result might indicate that some foreigners have better information about NK through various channels.

Fourth, while GY treat foreigners as a uniform group, we dissect the foreigners into various subgroups leveraging the unique feature of microstructure data we have: (1) individuals versus institutions; (2) residents versus non-residents in SK; (3) those from countries having diplomatic relations with NK versus those from countries that do not.

Fifth, while GY work with 13 events in total, we study 74 events (10 tests of nuclear weapons or LRMs, 13 acts of military aggression, 21 rumors/reports about testing, 21 events of NK claims to test nuclear weapons in the near future, and nine military threats). These come from our exhaustive hand collection of 292 events associated with NK over the period of 1999 2012, including most of the diplomatic gestures of NK and surrounding countries. To the best of our knowledge, our collection of events is the largest in the literature on NK. Since nuclear weapons testing is preceded by either forewarnings by NK or rumors or reports from other countries, we capture these pre-warnings to see if investors respond significantly. Also, we investigate the stock price responses to NK military threats, and find that the threats generate significant negative responses. While GY study the 53 largest stocks in SK, using daily stock return data, we work with all listed companies in SK using both microstructure and daily data.

Cutler, Poterba, and Summers (1989) document that major political events have relatively little impact on the US stock market. However, strands of literature have found significant impacts of political events on stock markets. Barro (1991), Mauro (1995) and Alesina et al. (1996) argue that political instability has a negative effect on economic growth. Ahn, Chay, and Jeon (2010) study the impacts of news about NK-SK relations based on 37 events and 46 Korean firms, and find that news about military attacks has negative impacts on the stock prices of firms having production facilities in Kaesong, a city in NK that was opened for economic cooperation projects between North and South Korea from 2000. 
He, Nielsson, and Wang (2012) find that non-violent events of political tension between China and Taiwan result in a drop of two percentage points in the Taiwanese stock market index on the days of these events. They find that the abnormal returns are larger in magnitude if the firms are supporting the pro-independence party and if they are located within the range of missiles from China. The effects of realized and perceived political instability on stock markets have also been studied. Fisman, Hamao, and Wang (2012) study the market reaction to increased cultural aversion in Sino-Japanese relations. Abadie and Gardeazabal (2003) find significant negative economic impacts of guerrilla attacks in the Basque Country, Spain. Besley and Mueller (2012) study the political conflict in Northern Island, and find housing prices to be significantly affected by the chances of having military conflict and killings of people in the region, using a Markov switching model for switching from peace to conflict and vice versa. Zussman and Zussman (2006) use a stock market event study to identify the impacts of political risk on stock prices from Israeli data. They find that investors react positively to assassinations of senior military leaders of Palestine, but negatively to assassinations of senior Palestinian political leaders, with the reason for this contrast being because the killing of political leaders are counterproductive in terms of peace talks in the region and increased geopolitical risk. Rigobon and Sack (2004), Surowiecki (2004), Chen and Siems (2004), Wolfers and Zitzewitz (2009), Zussman and Zussman, and Nilsen (2008) find that financial markets are sensitive to political, diplomatic, and military developments. Boyd, Hu, and Jagannathan (2002) find that same macroeconomic news could receive different stock market response depending on whether its information content is about lower discount rate or lower future cash flow. To the best of our knowledge, this is the first study in the literature to use microstructure data and short selling data to examine the behaviors of international traders and the real time impacts of geopolitical risk.

\section{Data}

To make our study complete, we start by extensively collecting 292 events among all diplomatic and military interactions of NK involving SK, the US, and the multi- 
party talks during the sample period of 1999 2012. This is a union of 162 events of our own collection and 237 events compiled by the US website, Arms Control (www.armscontrol.org). For our own collection, we use the papers in the literature (Ahn, Chay, and Jeon, 2010; Gerlach and Yook, 2013; and Lee, 2006) and search through documents, such as the Defense Annals in SK, Google, and news articles of major media outlets, such as the Chosun Ilbo, the Dong-A Ilbo, the Hankyore, and the Joong-Ang Daily. We narrow our focus down to 74 events for this paper, and classify them into five groups: (1) tests of nuclear weapons (Nuke, hereafter) and LRMs ( $\mathrm{N}=10)$; (2) military aggressions $(\mathrm{N}=13)$; (3) external rumors and reports about forthcoming NK Nuke/LRM testing; (4) NK declarations to test Nuke/LRM in the near future; and (5) NK military threats to bring "sea of fire" to SK. We classify the events of (1) NK beginning to restart its nuclear facilities and (2) NK withdrawing from the Non-Proliferation Treaty on January 10, 2003 in the first group, because, unlike NK's declarations of forthcoming Nuke testing, these events clearly signaled NK's intention to develop nuclear weapons and to move into a different state of nature permanently. The data on daily stock prices and the accounting information on public companies in South Korea are from FN Guide. The Korean microstructure data of 1999 2012 is from the KRX.

\section{Results}

\section{Daily event study using KOSPI index returns}

We first investigate the market level movements in response to the geopolitical risk events. For each category of event listed in the previous subsection, we compute the abnormal returns using the KOSPI index value. An abnormal return is defined as the index return on a trading day in the event window minus the expected daily index return (which is the average index return over the estimation window of $[-130,-11]$ trading days). The results are shown in Table 2 below. The t-statistics using Boehmer, Musumeci, and Poulsen (1991) are shown in every second row. Some readers may wonder if the results that we report here are merely attributable 


\section{Table 1: Classification of Events}

\begin{tabular}{|c|c|c|}
\hline & $\begin{array}{l}\text { date of } \\
\text { breakout }\end{array}$ & Event \\
\hline \multicolumn{3}{|c|}{ Nuke/LRM testing } \\
\hline 1 & $12 / 22 / 2002$ & $\begin{array}{l}\text { NK stop the CCTV on their nuclear facilities, and they removed } \\
\text { the cover of nuclear fuel }\end{array}$ \\
\hline 2 & $01 / 10 / 2003$ & NK get out of NPT \\
\hline 3 & $02 / 24 / 2003$ & NK test long range missles in the East Sea \\
\hline 4 & $03 / 10 / 2003$ & NK launches non-ballistic missiles \\
\hline 5 & 07/05/2006 & Daepodong 2 test launching \\
\hline 6 & $10 / 09 / 2006$ & First nuclear testing of $\mathrm{NK}$ \\
\hline 7 & 04/05/2009 & Launching Daepodong 2 new version \\
\hline 8 & $05 / 25 / 2009$ & 2nd nuclear testing \\
\hline 9 & $04 / 13 / 2012$ & NK fails in launching a rocket \\
\hline 10 & $12 / 12 / 2012$ & $\begin{array}{l}\text { NK succeeds in sending a long-range rocket carrying a satellite } \\
\text { into orbit }\end{array}$ \\
\hline \multicolumn{3}{|c|}{ Military aggression } \\
\hline 1 & 06/08/1999 & The first battle of Yeonpyeong \\
\hline 2 & $11 / 27 / 2001$ & North and South Korean forces exchange fire \\
\hline 3 & 06/29/2002 & The second battle of Yeonpyeong \\
\hline 4 & $01 / 14 / 2003$ & ROK and NK soldiers exchange machine gun fire \\
\hline 5 & 07/17/2003 & North and South Korean forces exchange fire at the DMZ \\
\hline 6 & 08/27/2003 & KPA soldiers fire rounds that strike a UNC guardpost \\
\hline 7 & $07 / 31 / 2006$ & North and South Korean forces exchange fire near Yanggu \\
\hline 8 & 08/06/2007 & KPA soldiers and 12th Infantry Division troops exchange fire. \\
\hline 9 & $11 / 10 / 2009$ & Battle of Daecheong \\
\hline 10 & $01 / 27 / 2010$ & Around thirty NK artillery shells shot into the NK's coastal waters. \\
\hline 11 & 03/26/2010 & $\begin{array}{l}\text { The South Korean patrol ship Cheonan is sunk near the South } \\
\text { Korean-NK maritime border. }\end{array}$ \\
\hline 12 & $08 / 09 / 2010$ & NK artillery shells into the NK's coastal waters \\
\hline 13 & $11 / 23 / 2010$ & $\begin{array}{l}\text { NK fires artillery rounds at the SK island of Yeonpyeong, } 200 \text { of } \\
\text { which hit the island killing civilians and soldiers }\end{array}$ \\
\hline \multicolumn{3}{|c|}{ Rumor report of Nuke/LRM (21 events) } \\
\hline & 02/03/1999 & $\begin{array}{l}\text { CIA reports capability of NK to launch ICBC Taepodong to Alaska } \\
\text { in the near future }\end{array}$ \\
\hline \multicolumn{3}{|c|}{ NK claimed Nuke/LRM (21 events) } \\
\hline & 02/10/2005 & $\begin{array}{l}\text { NK declares it has nurlear weapons and stops participating in } 6 \\
\text { party talks }\end{array}$ \\
\hline \multicolumn{3}{|c|}{ Military Threat (9 events) } \\
\hline & $02 / 27 / 2011$ & $\begin{array}{l}\text { NK threatens to turn Seoul into a "sea of fire" in response to } \\
\text { the Key Resolve exercises, planned long in advance }\end{array}$ \\
\hline
\end{tabular}

Notes: The events are of our own collection and events compiled by the US website, Arms Control (www.armscontrol.org). For our own collection, we use the papers in the literature (Ahn, Chay, and Jeon, 2010; Gerlach and Yook, 2013; and Lee, 2006) and search through documents, such as the Defense Annals in SK, Google, and news articles of major media outlets, such as the Chosun Ilbo, the Dong-A Ilbo, the Hankyore, and the Joong-Ang Daily. 
to short-run overreactions. Therefore, we run longer window event study in Figure 1, in which we start to accumulate the abnormal returns from [-1] trading day until the trading date on the horizontal axis. For the analysis in Figure 1, to steer clear of the effect of confounding events, we remove the observations if any NK-related events took place less than six days before the event being observed.

Investors' responses to nuclear weapons or LRM testing are negative and significant $(-1.59 \%$ with t-stat of -2.08$)$ over a $[-1,1]$ trading day window relative to the actual setting off of the weapons. This response does not seem to be an overreaction but permanent. In Panel A of Figure 2, we find the CAR[-1, 7] to be $-2.23 \%$ (t-stat=4.84). This confirms our hypothesis that the nuke/LRM testing by NK over the last decade has had significant information content that the level of geopolitical risk has changed significantly. Considering the fact that NK sometimes pre-warns the testing of nukes/LRMs, some readers may question whether the investor response to the actual tests should be insignificant if rational expectations are formed and if investors believe NK's words. If so, investors should respond significantly at either the advance warnings or the rumors about nuclear weapons testing. Our event study however reveals that this is not the case. Stock market participants do not seem to take the advance warnings of NK or the rumors from intelligence sources as informative. Only when the actual testing happens do we see significant investor responses.

\section{Table 2: Short-run Event Study on KOSPI Index Returns}

\begin{tabular}{|c|c|c|c|c|c|c|}
\hline \multirow{2}{*}{$\begin{array}{l}\text { Expected return: } \\
\text { Event group }\end{array}$} & & \multicolumn{5}{|c|}{ 120-day moving average } \\
\hline & $\mathrm{N}$ & {$[0]$} & {$[0,1]$} & {$[0,2]$} & {$[-1,0]$} & {$[-1,1]$} \\
\hline \multirow[t]{2}{*}{ Nuke/LRM Testing } & 10 & $-0.73 \%$ & $-1.02 \%$ & $-1.57 \%$ & $-1.29 \%$ & $-1.59 \%$ \\
\hline & & -1.41 & -1.30 & -1.86 & -2.17 & -2.08 \\
\hline \multirow[t]{2}{*}{ NK claimed Nuke/LRM launching } & 21 & $0.00 \%$ & $0.29 \%$ & $0.09 \%$ & $0.18 \%$ & $0.47 \%$ \\
\hline & & 0.00 & 0.58 & 0.20 & 0.38 & 0.76 \\
\hline \multirow[t]{2}{*}{ Rumor Report about Nuke/LRM of NK } & 21 & $0.05 \%$ & $0.62 \%$ & $0.43 \%$ & $-0.07 \%$ & $0.51 \%$ \\
\hline & & 0.11 & 1.06 & 0.65 & -0.11 & 0.63 \\
\hline \multirow[t]{2}{*}{ Military aggression of NK to SK } & 13 & $-0.29 \%$ & $-1.23 \%$ & $-0.79 \%$ & $1.00 \%$ & $0.01 \%$ \\
\hline & & -1.05 & -1.88 & -1.22 & 1.30 & 0.01 \\
\hline \multirow[t]{2}{*}{ Military threat of NK to SK } & 9 & $-0.41 \%$ & $-0.68 \%$ & $-0.17 \%$ & $-1.52 \%$ & $-1.79 \%$ \\
\hline & & -1.95 & -1.70 & -0.30 & -3.87 & -3.28 \\
\hline
\end{tabular}

Notes: KOSPI index returns are using 120-trading day moving average of KOSPI index return as expected return. An abnormal return is defined as the daily KOSPI index return minus the average return over the estimation window of [-130, -11] trading days. 


\section{Figure 1: Event Study of Military and Diplomatic Actions Involving North Korea (for non-contaminated observations only)}

Panel A. ACAR $[-1, t]$ : NK action of Nuke/LRM launching $(\mathrm{N}=5)$

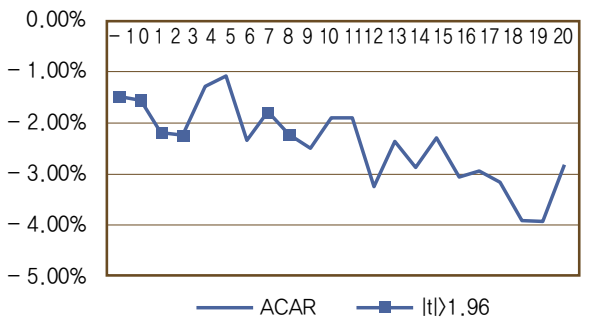

Panel C. ACAR $[-1$, t]: NK claimed Nuke/LRM launching $(\mathrm{N}=14)$

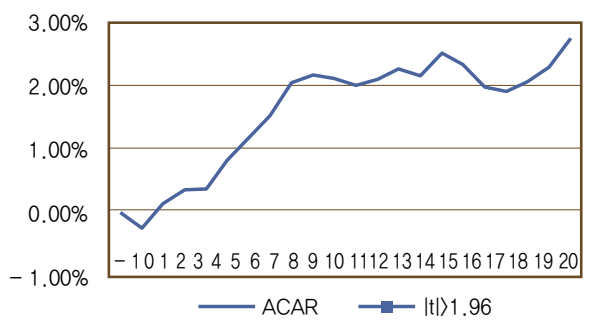

Panel B. ACAR[-1,t]: NK claimed Nuke/LRM launching $(\mathrm{N}=14)$

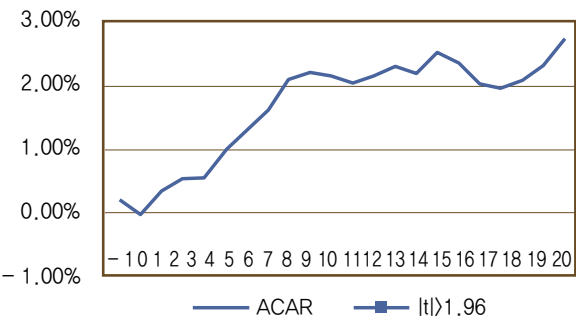

Panel D. ACAR $[-1, t]$ : Military aggression of NK to $\mathrm{SK}(\mathrm{N}=6)$

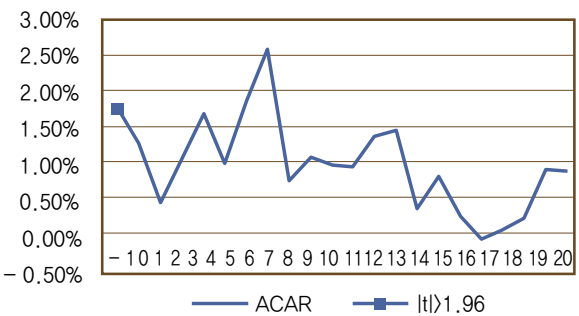

Notes: An abnormal return is defined as the daily KOSPI index return minus the average return over the estimation window of $[-130,-11]$ trading days. We accumulate the abnormal returns from one trading day before the first date of the event's being reported, and then keep accumulating until the trading day shown on the horizontal axis. If the average cumulative abnormal return is significant at the $10 \%$ level or less, we indicate it with box dots. The t-statistic is constructed using Boehmer, Musumeci, and Poulsen (1991), to control for event-induced volatility. To steer clear of the effect of confounding events, we remove the observations if any NK-related events took place less than six days before the event being observed.

The investor response to actual major military aggression by NK turns out to be not significant or an overreaction at best. The average $\mathrm{CAR}[0]$ is $-1.23 \%$ (t-stat $=1.88$ with $\mathrm{N}=13$ ), but as we look at the longer window event study in Figure 1, we see an immediate reversal on the next trading day. This confirms again our hypothesis that investors take military attacks by NK to be "business as usual."

In contrast, we find the stock market response to military threats by NK to be negative and significant. The cumulative abnormal return over a $[-1,1]$ event window 
is $-1.79 \%$, with a t-stat of -3.28 . However, since only two of these events are noncontaminated, we do not make further inferences. For sure, these are events distinct from the advance warnings by NK of exploding nuclear weapons or launching LRMs for testing.

Our next question is whether the magnitude of investor response changes over time. If the transition from having a negotiation counterparty without nuclear weapons to one with nuclear weapons is finished, after a certain point, nuclear weapons testing would start to become business as usual and investors would no longer respond. And the magnitude of the investor response would thus shrink over time. Therefore, in Panel A of Figure 2, we show the CAR of each event of Nuke/LRM testing. We find that the investor response was the worst on December 22, 2002, the day when NK began to restart its nuclear facilities. As the testing of long-range missiles and nuclear weapons has continued, the direction of the CAR has been largely negative, while the magnitude has decreased slightly over time. Therefore, a significant part of the revision of beliefs seems to have taken place in the early stage. By the time NK launched its Daepodong 2 LRM on April 5, 2009, the market response was even slightly positive. When NK's recent LRM launch of December 12, 2012 succeeded, the market seemed to be responding as if there were no update needed in terms of the level of geopolitical risk, consistent with market efficiency (Fama, 1970).

\section{Figure 2: Stock Market Responses to NK Nuke/LRM Testing in Different Countries over Time}
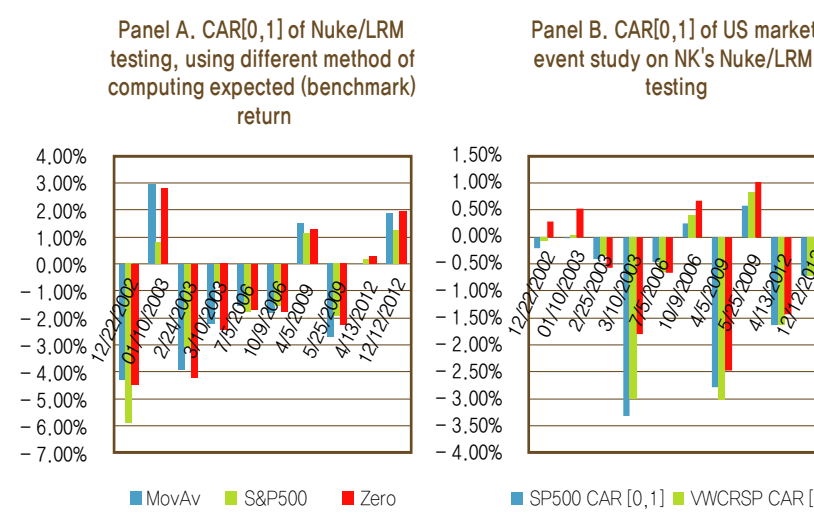
Panel C. CAR $[0,1]$ of Japanese and Hong Kong stock market response to NK's nuclear/LRM testings
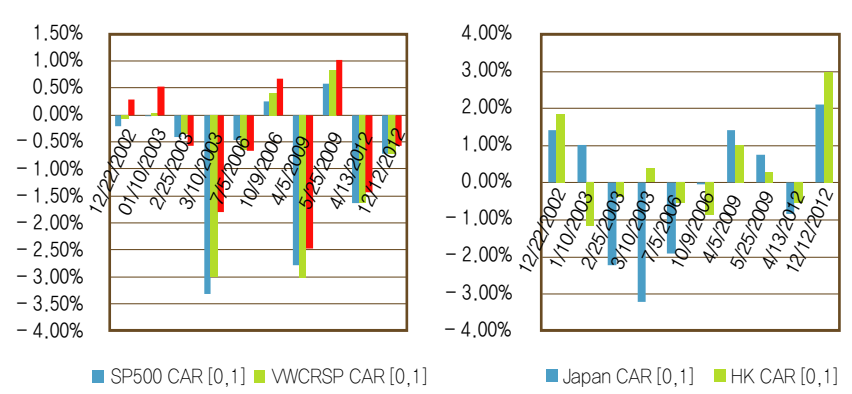

Note: The dates on the horizontal axis are the first trading days after the occurrences of events, and so may differ slightly from the dates in Tables 1 . 


\section{Daily event study using market index returns of the US}

As long as the US is a proclaimed counterparty of NK in the nuclear arms negotiations, and as long as NK's LRMs are targeting the North American continent, the testing of nuclear weapons may indicate a significant increase in geopolitical risk for the US as well. Therefore, we run a short-run event study of the S\&P500 index returns using the moving average method over a $[-130,-11]$ trading day estimation window. We find that the ACAR $[0,1]$ of the S\&P500 return for NK nuclear weapons/LRM testing is $-0.88 \%$ ( $\mathrm{t}$-stat=2.13), which means it is negative and significant at less than the $5 \%$ level. This result is robust when we use the value-weighted CRSP index $(-0.85 \%$ with a t-stat of 1.93$)$ and the equal-weighted CRSP index $(-0.50 \%$ with a t-stat of 1.37$)$. To save space, we do not tabulate them.

With the same logic as in the last subsection, we investigate the time series of investor responses in the US to the series of NK Nuke/LRM tests and show it in Panel B of Figure 2. We show the CAR $[0,1]$ of US market index returns. For each incident we use three different indices: S\&P500, value-weighted CRSP, and equal weighted CRSP. In contrast to what we find in the Korean stock market, the US market began to respond significantly from March 10, 2003 (-3.2\%: the day of a NK launch of a non-ballistic missile (still long-range)), and the magnitude of the negative response was similar on April 5, 2009 (the day of NK's launch of its LRM, Daepodong 2). The response is still negative in 2012. Interestingly, the US response is slightly positive on the days of the first and second nuclear weapon tests (October 9, 2006 and May 25, 2009), and what we can infer from this is that US investors began to take the geopolitical threat of NK very seriously as NK's LRM program advanced in terms of distance to reach closer to the US mainland. What this implies may be that the US would more readily take action against any greater nuclear/ LRM threat, to protect its own territory. Again, the magnitude of responses to LRM launches seems to have been diminishing since the Daepodong 2, indicating that most of the updating was done until 2009.

We also investigate the stock price responses in Japan and Hong Kong, using the Nikkei (Japan) and Hang Seng (Hong Kong) indexes downloaded from Yahoo!Finance. We again use the 120-trading day moving average over the estimation window of 
[-130, -11] trading days as the expected return, but do not find any significant abnormal returns (untabulated to save space). We plot the time series of $\operatorname{CAR}[0,1]$ for each Nuke/LRM test in Panel C. Because China and Hong Kong are not really targeted by NK, we do not find any significant pricing pattern in the Hong Kong market. The returns on the Nikkei index were the most negative on the day when NK launched non-ballistic missiles into the sea between Japan and the Korean peninsula on March 10, 2003. For Japan, as the range of NK's LRMs grew beyond Japanese territory and reached closer to the US, the stock price response became insignificant. This pattern might be attributable to two potential offsetting effects. On the one hand, the rise in geopolitical risk would reduce Japanese stock prices, just like in SK and the US. On the other hand, the increased risk from NK would trigger Japanese rearmament, which would spur production in military-related industries and in turn increase stock prices.

\section{Analysis of stock level responses in SK}

In Section 1 we investigated the market-wide response to various geopolitical risk events on the Korean peninsula. In this section we study the cross-sectional variation in stock price responses among all 1,715 individual listed firms in SK using a multiple regression framework. We use the event day return as the dependent variable and the firm characteristics as explanatory variables or controls. Ever since 2000 , the year of the first inter-Korean summit, as a symbol of economic cooperation between NK and SK, the two countries established a special economic zone in the territory of NK only 10 kilometers (6.2 miles) north of the DMZ (demilitarized zone), called the Kaesong Industrial Region (KIR, hereafter). There are 72 public firms with production plants located in the KIR, and for this group of firms geopolitical tensions between NK and SK would negatively affect their production in terms of cash flow and risk.

For example, some of the free trade agreements that SK has entered into with different foreign countries take different stances in terms of recognizing products from the KIR as products of SK (or of NK), and these stances have changed depending upon the hawkishness of the SK ruling party. Therefore, the price competitiveness 
of these products has been affected by geopolitical tensions, which has naturally affected cash flows. In addition, every now and then NK has leveraged the SK workers in the KIR as a bargaining tool, for example expelling SK government officials in 2008. For SK employees working in the KIR, there has always been the worst case possibility of becoming taken hostage by NK, which would cause tremendous costs to SK companies. NK eventually closed the KIR in 2013, at the peak of the tensions surrounding its nuclear testing. We therefore hypothesize that the stock price responses to military/diplomatic tension would be especially negative for companies with exposure in the KIR. In Appendix C we list these companies, and label their stocks "Econ coop stocks," meaning stocks of companies involved in economic cooperation with NK. We construct our list by combining the lists in Ahn, Chay, and Jeon (2010) and those used in Shinhan Bank and Korea Investment Securities Co.

There are also some companies that produce defense industry products, such as tanks and heavy machinery. We label their stocks "Defense stocks," and hypothesize that military tensions between North and South Korea may be good news for them because of the increased chance of selling more products to the Department of Defense. Ahn, Chay, and Jeon (2010) find that bad news in NK-SK relations results in positive responses of stocks in the defense industry. Our list of 41 "Defense" stocks is also given in Appendix C.

We control for foreign ownership, firm size (log of total assets), profitability (ROA: operating income before depreciation divided by assets), financial risk (leverage ratio), and information asymmetry ( $R \& D$ margin: total $R \& D$ expenses divided by revenues). Given that the geopolitical risk coming from NK is such an important factor in investing in SK, foreign investors might have chosen certain stocks in SK to minimize this geopolitical risk in the first place. Therefore, for a stock with high foreign ownership, the investor response to events of high tension between NK and SK should be less negative. Since we are investigating the cross-sectional variations among all stocks in the stock market, we use the raw returns instead of abnormal returns as our dependent variable. We control for industry fixed effects. Because we take repeated observations from the same companies for different events, we use clustered standard errors at the firm level. Our empirical model is as follows:

$$
\operatorname{Ret}\{0\}_{i, t}=\beta_{1} 1_{\{\text {Econ Coop }\}_{i}}+\beta_{2} 1_{\left\{\text {Defense }_{i}\right.}+\gamma \text { Controls }_{i, t}+\text { IndusturyFE }_{i, t}
$$




\section{Table 3: Regression Analysis of Stock Returns on Days of NK Actions (non-contaminated events only)}

\begin{tabular}{|c|c|c|c|c|c|}
\hline \multicolumn{6}{|c|}{ Dependent variable: Return [0] } \\
\hline & $\begin{array}{l}\text { [1] } \\
\text { NK action of } \\
\text { Nuke LRM } \\
\text { launching }\end{array}$ & $\begin{array}{l}\quad[2] \\
\text { NK claimed } \\
\text { Nuke LRM } \\
\text { launching }\end{array}$ & $\begin{array}{c}\text { [3] } \\
\text { Rumor Report } \\
\text { about Nuke/LRM } \\
\text { of NK }\end{array}$ & $\begin{array}{c}{[4]} \\
\text { Military } \\
\text { aggression of } \\
\text { NK to SK }\end{array}$ & $\begin{array}{l}{[5]} \\
\text { Military threat } \\
\text { of NK to SK }\end{array}$ \\
\hline $1\{$ Econ coop stock\} & $\begin{array}{l}-0.007^{* * *} \\
(-2.62)\end{array}$ & $\begin{array}{l}-0.004^{* * *} \\
(-4.24)\end{array}$ & $\begin{array}{r}0 \\
(-0.12)\end{array}$ & $\begin{array}{l}-0.001 \\
(-0.48)\end{array}$ & $\begin{array}{l}0.002 \\
(0.57)\end{array}$ \\
\hline $1\{$ Defense stock\} & $\begin{array}{l}-0.004 \\
(-0.70)\end{array}$ & $\begin{array}{l}0.003 \\
(1.34)\end{array}$ & $\begin{array}{r}0 \\
(0.14)\end{array}$ & $\begin{array}{l}0.001 \\
(0.34)\end{array}$ & $\begin{array}{l}0.003 \\
(1.08)\end{array}$ \\
\hline Foreign ownership & $\begin{array}{l}-0.009 \\
(-1.54)\end{array}$ & $\begin{array}{l}0.007^{*} \\
(1.89)\end{array}$ & $\begin{array}{l}0.006^{*} \\
(1.69) \\
\end{array}$ & $\begin{array}{l}-0.013^{* * *} \\
(-3.44)\end{array}$ & $\begin{array}{l}-0.008 \\
(-0.98)\end{array}$ \\
\hline In(Total Assets) & $\begin{array}{l}0.004^{* * *} \\
(6.66)\end{array}$ & $\begin{array}{r}0 \\
(-0.48) \\
\end{array}$ & $\begin{array}{l}0.001^{* * *} \\
(4.10)\end{array}$ & $\begin{array}{r}0 \\
(0.06)\end{array}$ & $\begin{array}{l}-0.001 \\
(-0.98)\end{array}$ \\
\hline $\mathrm{ROA}$ & $\begin{array}{l}-0.008 \\
(-1.12)\end{array}$ & $\begin{array}{l}-0.003 \\
(-0.55)\end{array}$ & $\begin{array}{l}-0.009^{* *} \\
(-2.05)\end{array}$ & $\begin{array}{l}0.003 \\
(0.56)\end{array}$ & $\begin{array}{l}0.007 \\
(0.76)\end{array}$ \\
\hline Leverage Ratio & $\begin{array}{l}-0.008^{* *} \\
(-2.00)\end{array}$ & $\begin{array}{l}-0.007^{* *} \\
(-2.47)\end{array}$ & $\begin{array}{l}-0.003 \\
(-1.21)\end{array}$ & $\begin{array}{l}0.004 \\
(1.20)\end{array}$ & $\begin{array}{l}-0.003 \\
(-0.77)\end{array}$ \\
\hline R\&D Margin & $\begin{array}{r}0 \\
(-0.00)\end{array}$ & $\begin{array}{l}-0.003 \\
(-0.32)\end{array}$ & $\begin{array}{l}0.004 \\
(0.48)\end{array}$ & $\begin{array}{l}0.018^{* *} \\
(2.01)\end{array}$ & $\begin{array}{r}-0.01 \\
(-0.67)\end{array}$ \\
\hline constant & $\begin{array}{l}-0.068^{* * *} \\
(-6.96)\end{array}$ & $\begin{array}{l}0.002 \\
(0.32)\end{array}$ & $\begin{array}{l}-0.02^{* * *} \\
(-3.67)\end{array}$ & $\begin{array}{l}-0.003 \\
(-0.44)\end{array}$ & $\begin{array}{l}0.008 \\
(0.78)\end{array}$ \\
\hline Industry FE & Yes & Yes & Yes & Yes & Yes \\
\hline $\mathrm{N}$ & 5225 & 13834 & 14250 & 5882 & 2691 \\
\hline Adj.R2 & 0.014 & 0.002 & 0.004 & 0.008 & 0.021 \\
\hline
\end{tabular}

Notes: Standard errors are clustered at the firm level. *, **, and $* * *$ represent statistical significance at the $10 \%, 5 \%$, and $1 \%$ levels, respectively.

We run the regressions for each different group of events, and the results are shown in Table 3:

First and foremost, we find that the stocks of companies involved in economic cooperation between NK and SK are hit hard by events of geopolitical tension such as nuclear weapons testing or announced plans by NK to test Nukes/LRMs. Contrary to our conjecture above, we do not find defense stocks to be significantly affected by geopolitical risk events. This may be because the increased tension does not materially increase the production of weapons for the arsenal or military facilities in SK. We also find some evidence of flight to quality when geopolitical tensions increase. Specifically, when nuclear testing is carried out by NK, (1) the returns on small stocks seem to be worse than those on large stocks, and (2) the returns on high leverage stocks seem worse than those on low leverage stocks. Firms with high foreign owner- 
ship seem to perform better when there are rumors or reports or NK announcements of plans for testing Nukes/LRMs. However, when military aggression takes place these firms seem to suffer more on the days of those events. Given that the investor response to NK military aggression ends up being an overreaction, it might be the case that some unsophisticated investors (presumably domestic individuals) in firms with high foreign ownership are overreacting by being overly conscious of foreign investors' potential selling pressures.

\section{Analyzing bid-ask spreads}

When a negative geopolitical event takes place, if the event is informative about the future cash flows and risks of South Korean firms, investors should revise their beliefs and reallocate their assets accordingly. If some investors have better information than others before geopolitical events, the adverse selection cost component of the bid-ask spread will increase. For example, when NK plans a surprise attack on SK territory, some investors may have better information through their professional or personal networks with the intelligence services. Some foreign investors may have better information if their countries have diplomatic relations with NK. In this subsection, therefore, we investigate the bid-ask spreads of stocks in SK related to events of NK Nuke/LRM testing and military aggression.

For each stock we first measure the effective spread for each transaction in a day. The effective spread is computed as the ask price minus the bid price divided by the midpoint between them. To avoid the noisiness of the market in the beginning and ending 30 minutes of the trading sessions, we take only the trades made during the time segment between 9:30 am and 2:30 pm (McInnish and Wood, 1992). For each stock on each trading day, we compute the average of the effective spread. Next, over the estimation window of $[-40,-11]$ trading days, we estimate the mean of the daily average effective spreads. And then, for each trading day over the event window of $[-5,5]$ trading days, we first compute the abnormal spread for each stock by subtracting the mean of its daily average effective spread from the daily average effective spread. Then we finally compute the mean of the abnormal spreads across all stocks. To obtain the standard errors, we run bootstrapping with 1,000 replications 
based on the sample. If the average abnormal effective spread is significantly different from zero with a statistical significance of $10 \%$ (|z-stat $\mid>1.96)$, we represent it with a colored dot.

As predicted, we find that the daily average effective spread becomes abnormally high on the day of the event concerned, which may indicate either that the information asymmetry increases or the liquidity dries up. A more interesting finding is that the spread starts to increase significantly even four trading days before the outbreaks of military aggression and one day before Nuke/LRM tests. Before we jump to any conclusions about this, however, we first investigate the liquidity of the stocks to see if such increases in bid-ask spreads are attributable to the drying up of liquidity.

\section{Figure 3: Time Series of Average Abnormal Bid-ask Spreads during Geopolitical Risk Events}

Avg. Abnormal effective spread surrounding NK events (in bps)

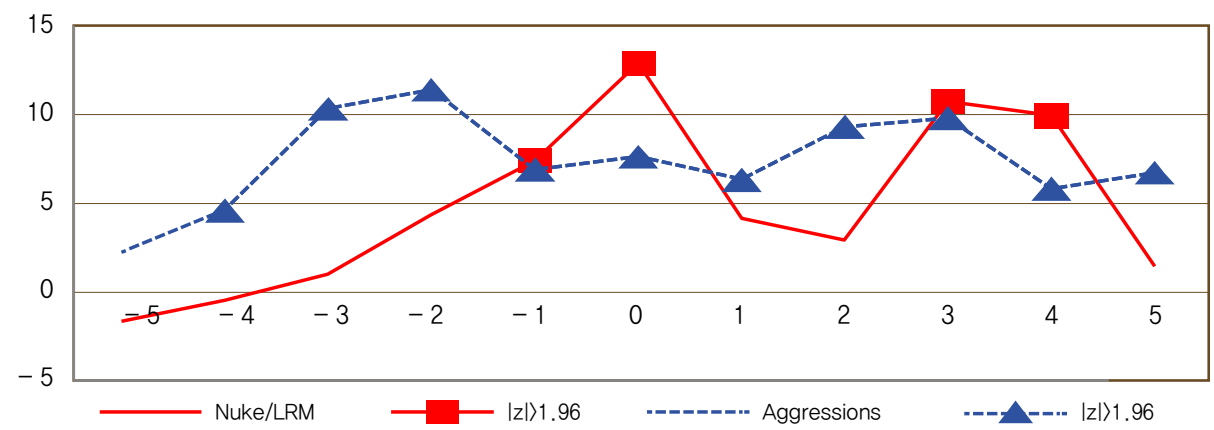

Notes: For each stock we first measure the effective spread for each transaction in a day. The effective spread is computed as the ask price minus the bid price divided by the midpoint between them. To avoid the noisiness of the market in the beginning and ending 30 minutes of the trading sessions, we only take the trades made during the time segment between 9:30 am and 2:30 pm. For each stock on each trading day, we compute the average of the effective spread. Then over the estimation window of $[-40,-11]$ trading day, we estimate the mean of the daily average effective spread. Then for each trading day over the event window of $[-5,5]$ trading day, for each stock we first compute the abnormal spread by subtracting the mean of the daily average effective spread, then we compute the mean of the abnormal spread across all the stocks. If the average abnormal effective spread is significantly different from zero with the statistical significance of $10 \%(\mid z$-stat $\mid>1.96)$ we represent it with a color dot. Z-statistic is obtained through bootstrapping with 1,000 replications. The results are robust when we represent (|z-stat|>2.58). 


\section{Daily abnormal volume event study}

In this subsection we study how the daily trading volume changes at around the days of the events. If the event is informative and the price change is permanent under market efficiency and a frictionless market where information is common knowledge, the price change will not be accompanied by a significant increase in trading volume (Milgrom and Stoke, 1982). However, if NK's testing of nuclear weapons and LRMs distracts investors (Hirshleifer, Lim, and Teoh, 2009), liquidity would dry up due to a lower trading volume, which would partly explain the increase in bid-ask spread in the previous subsection. On the other hand, if the event merely draws attention and triggers widespread disagreement among investors, the trading volume would rise significantly. We analyze the abnormal trading volume at the aggregate market level. Consistent with our return event study in Figure 1, we set up our estimation window to be [-130, -11] trading days and the event window [-1, 20]. For each trading day we compute the abnormal trading volume by subtracting the average trading volume over the estimation window from the event day trading volume. And then, for the given event classes that are not confounded by other events from our exhaustive collection of 292 events, we compute bootstrap z-statistics by replicating 1,000 times. If the abnormal share turnover is significantly different, with an absolute value of $z$-statistic greater than 1.96 , we indicate it with a box dot. The results are shown in Figure 4. We do find significant changes in liquidity in the stock market. Sixteen trading days after Nuke/LRM testing we detect significant declines in trading volume, but 16 days is too long to be linked to the events. For at least a handful of days around the day of an event, we do not see meaningful changes in trading volumes, making it hard for us to conclude that the increase in bid-ask spread found in the previous subsection is attributable to the liquidity issue. Rather, the results make it reasonable to attribute the bid-ask spread change to possible information asymmetry among investors caused by some investors having better information.

One possibility is that investors from countries having better diplomatic networks with NK are trading based upon their own private information. Some of these potential candidate investors may include foreigners of countries with diplomatic relations with NK and investors who have connections to various intelligence services. Other 
potential candidates are domestic individuals or institutions having better connections with intelligence services in various countries. When a trader has advance negative information about geopolitical risk, he/she has several ways of profiting from it. One is to take long positions on put options of the stocks of the country involved, as in Poteshman (2006). Unfortunately, we do not have the trading data of the option markets in SK. Another way of profiting is through the short selling of stocks or indices, which leads us to the next subsection.

Figure 4: Abnormal Trading Volume Analysis

Panel A. Abn. Volume: NK action of Nuke/LRM launching ( $\mathrm{N}=5)$

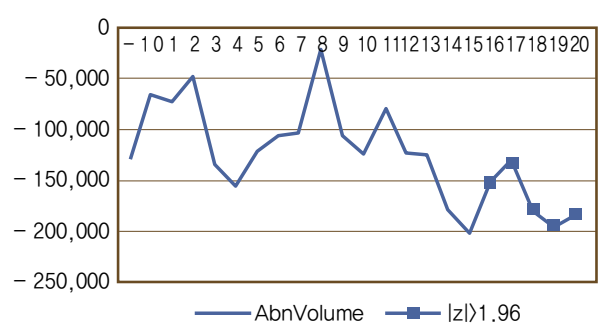

Panel C. Abn. Volume: Rumor/Report about Nuke/LRM of NK $(\mathrm{N}=15)$

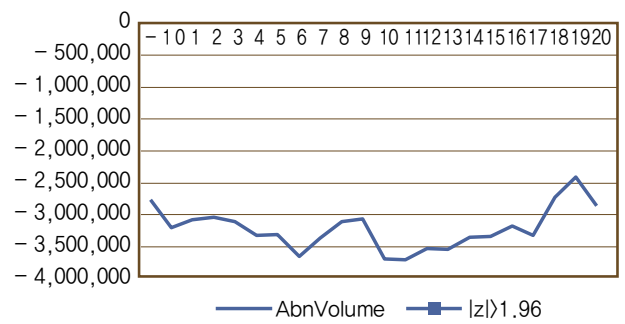

Panel B. Abn. Volume: NK claimed Nuke/LRM launching ( $\mathrm{N}=14)$

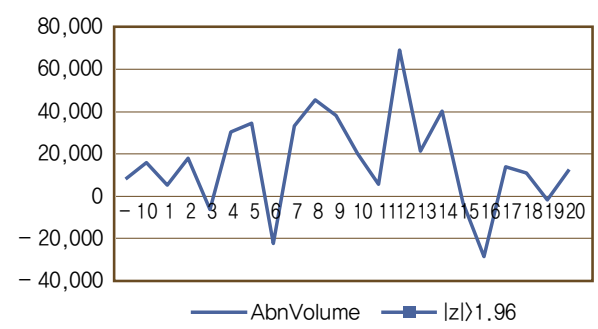

Panel D. Abn. Volume: Military aggression of NK to SK $(\mathrm{N}=6)$

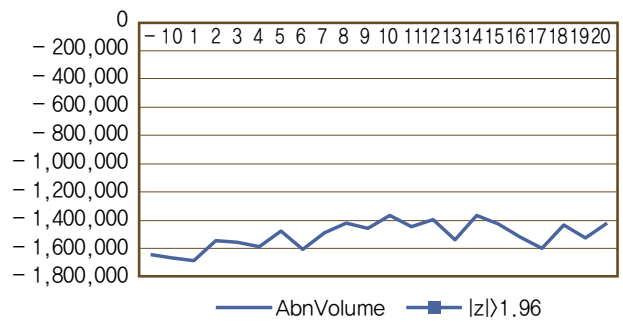

Notes: We set up our estimation window to be [-130, -11] trading days and event window to be $[-1,20]$. For each trading day we compute the abnormal trading volume by subtracting the average trading volume over the estimation window from the event day trading volume. Then for the given event class that are not confounded by other events from our collection of 292 events, we compute a bootstrap z-statistic by replicating 1,000 times. If the abnormal share turnover is significantly different with the absolute value of $z$-statistics greater than 1.96 , we present it with a box dot. 


\section{Volumes of short selling around the time of NK events}

The KRX data enables us to identify whether a sell order is a short sale or not, as in Kim and Jung (2013), and whether an order is coming from individual or institutional investors. Further, it gives information about the nationalities of the traders and the kinds of institutional investors concerned, such as brokerages versus asset managers. It also identifies whether a trade is associated with program trading and of which kind, for example index arbitrage. For institutional details about short selling in the Korean market, please refer to Kim and Jung (2013) or Lee and Wang (2013).

For foreign investors placing orders, the KRX data not only identifies whether they are individuals or institutional, but also whether they are resident or nonresident foreigners and what their nationalities are. While non-resident foreign individual investors are not active in short selling SK stocks, resident foreign individuals sometimes are. Also, when foreign institutions short sell Korean stocks, their nonresident counterparts offshore (headquarter) typically execute the transactions. We therefore focus on the short selling behaviors of resident foreign individual investors (RFInd) and non-resident foreign institutions (NRFInst). Moreover, because we conjecture that the behavior of foreign investors may be a function of the diplomatic relations of their home countries with NK, due to the potential information flow, we split the sample into foreigners from countries with diplomatic relations with NK (147 countries including China, Sweden, and Singapore) and from those without (100 countries including the US, Japan, and offshore South Korean citizens having permanent residency in foreign countries). We obtain the list of countries that have diplomatic relations with NK from the National Committee on North Korea's webpage (http://www.ncnk.org/), and Google searching.

We first set our estimation window to be $[-40,-11]$ trading days before the event, and our event window to be $[-5,5]$ trading days. For each stock we carry out the following process, for individual investors and institutional investors separately: We first calculate the short turnover, which is the short selling volume divided by the number of shares outstanding on a trading day. Next, over the estimation window, we compute the daily average short turnover of the stock. Then, on each trading 
day of the event window, we compute the abnormal short turnover, which is the actual minus the expected (average) short turnover. We then take the average abnormal short turnover across all stocks and across the series of events in the same category of event.

$$
{\text { Short } \text { Turnover }_{i, t, g}}=\frac{{\text { Short } \text { Volume }_{i, t, g}}_{\text {Shares outstanding }}^{i, t, g}}{}
$$

Average Abnormal short Turnover ${ }_{t, g}$

$$
=\frac{1}{I} \sum_{i=1}^{I}\left[\text { Short Turnover } \text { Th, }, g-\overline{\text { Short Turnover }_{i, g}}\right]
$$

where $\mathrm{i}$ is a subscript for each stock in the Korean market, $\mathrm{g}$ is a subscript for the investor sub-group, and $\mathrm{t}$ is a subscript for the trading day. The event window is $[-5$, -1] trading days, and is computed over the estimation window of [-40, -11] trading days. Figure 5 shows the average abnormal short turnover around the day of NK nuclear/LRM testing, and Figure 6 the average abnormal short turnover around the day of NK acts of military aggression. We bootstrap 1,000 times to obtain the standard error, and represent it with a colored dot when the average abnormal short turnover is statistically significant at the $5 \%$ level.

For the trading days before both groups of events we detect significant abnormal short selling volume coming from domestic individual investors and domestic institutions. We do not have hard evidence as to whether some of these investors may have had better information from NK or been more sensitive to expectations of forthcoming actions by NK. When we look at the behaviors of foreign investors before Nuke/LRM tests in Panel C of Figure 5, an interesting pattern arises. Nonresident foreign institutions from countries that have diplomatic relations with NK show a spike one day before the Nuke/LRM testing. The spike is not statistically significant, but the economic magnitude is large compared to the movements of domestic institutions. This suggests that some countries in the group with diplomatic relations with NK are disproportionately short selling greatly, while the rest are not involved in short sales. The graph also shows that non-resident foreign institutions from countries without diplomatic relations with NK are not short selling any more significantly than before. 


\section{Figure 5: Volumes of Abnormal Short Selling Surrounding NK Nuke/LRM tests}

Panel A. Avg Abn. Short volume by domestic individuals and insitutions surr. NK Nuke/LRM

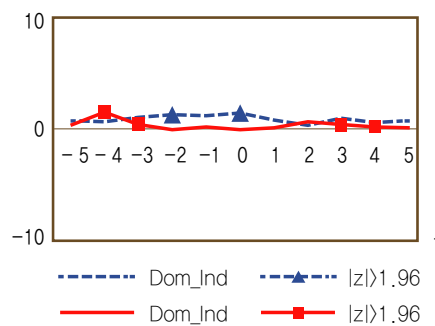

Panel B. Abnormal Short turnover by RFInd by countries with

Diplomatic relation with NK or not

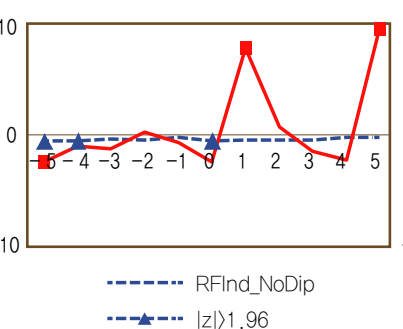

Panel C. Abnormal Short turnover by NRFInst. by countries with

Diplomatic relation with NK or not

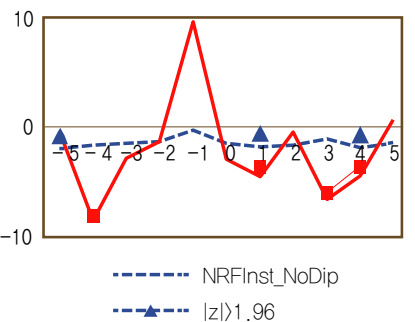

Notes: Short turnover is calculated as the short selling volume divided by total shares outstanding, which we then multiply by $1,000,000$ for better readability. Therefore, the unit on the vertical axis is one one-hundredth of a basis point. We first set our estimation window to be $[-40,-11]$ trading days before the event, and the event window to be $[-5,5]$ trading days. We first set our estimation window to be $[-40,-11]$ trading days before the event, and our event window to be $[-5,5]$ trading days. For each stock we carry out the following process, for individual investors and institutional investors separately: We first calculate the short turnover, which is the short selling volume divided by the number of shares outstanding on a trading day. Next, over the estimation window, we compute the daily average short turnover of the stock. Then, on each trading day of the event window, we compute the abnormal short turnover, which is the actual minus the expected (average) short turnover. We then take the average abnormal short turnover across all stocks and across the series of events in the same category of event. We bootstrap 1,000 times to obtain the standard error, and represent it with a colored dot when the average abnormal short turnover is statistically significant at the $5 \%$ level.

\section{Figure 6: Volumes of abnormal short selling surrounding NK acts of military aggression}

Panel A. Avg Abn. Short volume by domestic individuals and insitutions surr. NK Military Aggressions

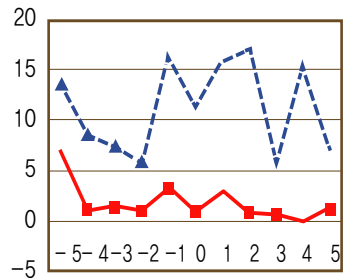

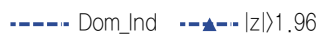

$\longrightarrow$ Dom_Inst $\rightarrow|z|\rangle 1.96$
Panel B. Abnormal Short turnover by RFInd by countries with Diplomatic relation with NK or not

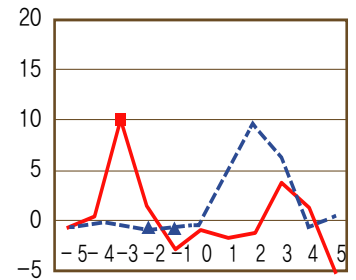

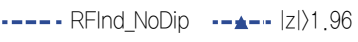

$\longrightarrow$ RFInd_YesDip $\longrightarrow$ - $|z|\rangle 1.96$
Panel C. Abnormal Short turnover by NRFInst by countries with Diplomatic relation with $\mathrm{NK}$ or not

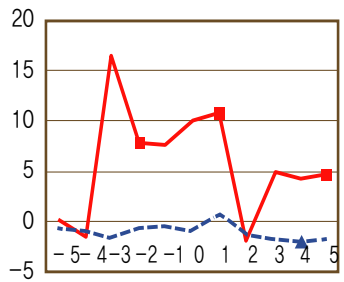

---n-- NRFInst_NoDip - - NRFInst_YesDip $\longrightarrow$ - $|z|\rangle 1.96$

Note: For the captions, please refer to notes to Figure 5. 
When we look at the behaviors of foreign investors before military attacks, in Panel C of Figure 6, another interesting pattern appears. Non-resident foreign institutions from countries having diplomatic relations with NK significantly short sells more than two days before the attacks. Recall that acts of military aggression bring an abnormal return of about $-1.23 \%$ ( $\mathrm{t}-\mathrm{stat}=1.88)$ on the day of the event. The spike in short turnover is both statistically and economically significant. Interestingly, again, the graph shows that non-resident foreign institutions from countries without diplomatic relations with NK do not short sell any more significantly than before. These pieces of evidence may suggest that some investors placing orders in countries with diplomatic relations with NK are leveraging their informational advantages by short selling stocks in advance. And we therefore delve deeper in the next subsection, and investigate which countries' institutions are short selling significantly more over this pre-event window utilizing the country codes.

\section{Conclusion}

The South Korean stock market enables us to identify the impacts of changes in geopolitical risk resulting from the transitioning by its belligerent communist neighbor beyond its northern border from a country without to a country with substantial capabilities in nuclear weapons and LRMs (Lee, 2013; and UPI, 2013). Moreover, NK's testing of weapons has been exogenous to the financial market of SK, and has been unpredictable due to NK's secretive nature. We find not only a $1.59 \%$ permanent decrease in the SK stock market index, but also a $0.88 \%$ decline in the US stock market at around the days of NK testing of nukes/LRMs. While the magnitude of the investor response in SK has diminished since 2009, that of the investor response in the US remains non-trivial especially as NK's LRM tests prove to be able to reach closer to the US mainland. We interpret from this that US investors take the threat of NK seriously now.

We also find significant information asymmetry among investors before the actual testing of nuclear weapons and LRMs or launches of surprise military attacks, which lead to significant increases in bid-ask spreads without changes in liquidity. 
In addition, we document a significant difference in short selling volume between the investors with better access to information of NK and those without. The information channel that we identify is diplomatic relations between NK and the home countries of the foreign institutions placing orders from outside SK. This result might imply a kind of geopolitical insider trading. Given the heavy US sanctions against financial institutions dealing with NK, it is difficult to conjecture that these short sellers are financing tools for the NK regime in the absence of account level identification of traders. Our contribution to the literature is that this is the first paper to use microstructure/short selling data in a geopolitical risk study of finance and to identify potential insider trading based on geopolitical information. 


\section{References}

Abadie, A. and J. Gardeazabal (2003), "The Economic Costs of Conflict: A Case Study of the Basque Country," American Economic Review, Vol. 93(1), pp. 113-132.

Ahn, H. J., J. B. Chay, and S. P. Jeon (2010), "The Impact of News about Relations between North and South Korea on the Stock Market," (Korean language paper of Korean Institute of Finance).

Alesina, A. and R. Perotti (1996), "Political Instability and Economic Growth," Journal of Economic Growth, Vol. 1(2), pp. 189-211.

Barro, R. J. (1991), "Economic Growth in a Cross Section of Countries," Quarterly Journal of Economics, Vol. 106(2), pp. 407-443.

Besley, T. and H. Mueller (2012), "Estimating the Peace Dividend: The Impact of Violence on House Prices in Northern Ireland," American Economic Review, Vol. 102(2), pp. 810-833.

Boehmer, E., C. M. Jones, and X. Zhang (2008), "Which Shorts Are Informed?," The Journal of Finance, Vol. 63(2), pp. 491-527.

Boehmer, E., J. Musumeci, and A. B. Poulsen (1991), "Event-study methodology under conditions of event induced variance," Journal of Financial Economics, Vol. 32, pp. 253-272.

Chen, A. H. and T. F. Siems (2004), "The Effects of Terrorism on Global Capital Markets," European Journal of Political Economy, Vol. 20(2), pp. 349-366.

Choe, S. (2013), "Tensions over North Korea Rattle the South's Economy and Its Foreign Investors," New York Times, April 6.

Choe, H., B.Kho, and R. Stulz (1999), "Do Foreigners Destabilize Stock Markets? The Korean Experience in 1997," Journal of Financial Economics, Vol. 54, pp. 227-264.

Cutler, D. M., J. M. Poterba, and L. H. Summers (1989), "What Moves Stock Prices?," Journal of Portfolio Management, Vol. 15, pp. 4-12. 
Da, Z., J. Engelberg, and P. Gao (2010), "In Search of Attention," The Journal of Finance, Vol. 66, pp. 1461-1499.

Fama, E. F. (1970), "Efficient Capital Markets: A Review of Theory and Empirical Work," The Journal of Finance, Vol. 25(2), pp. 383-417.

Falletti, S. (2014), "Experts Warn of 'Chernobyl' Risk at Yongbyon Nuclear Plant," HIS Janes's 360, January 26.

Fisman, R., Y. Hamao, and Y. Wang (2012), "The Impact of Cultural Aversion on Economic Exchange: Evidence from shocks to Sino-Japanese relations," working paper.

Ferguson, N. (2008), "The Ascent of Money," New York: Penguin Press.

Gerlach, J. R. and Y. Yook (2014), "Political Conflict and International Equity Investment: Evidence from North Korean Attacks,” Federal Reserve Board working paper.

He, Y., U. Nielsson, and Y. Wang (2012), "The Cost of Political Tension: An Anatomy," Toulouse School of Economics working paper.

Hirshleifer, D., S. S. Lim, and S. H. Teoh (2009), "Driven to Distraction: Extraneous Events and Underreaction to Earnings News," The Journal of Finance, Vol. 64, pp. 2289-2325.

Kim, A. Y. (2014), "Predicting the Choice of North Korea: a Big Data Approach," Nanyang Business School working paper.

Kim, A. Y. and H. Jung (2013), "Investor PSY-chology surrounding 'Gangnam Style,", Nanyang Business School working paper.

Lee, C. (2013), "White House says different strategy needed on N. Korea, Iran," Yonhap News Agency, September 24.

Lee, K. (2006), "The Impact of News about North Korea on the Stock and Foreign Exchange Markets," The Journal of North East Asian Economic Studies, Vol. 18(1), pp. 61-90.

Lee, K. and S. F. Wang (2013), "Are Foreign Short Sellers to Blame? Evidence from Daily Short-Selling in Korean Stock Market," Seoul National University working paper. 
Loughran, T. and B. McDonald (2011), "When is a Liability not a Liability? Textual Analysis, Dictionaries, and 10-K's," The Journal of Finance, Vol. 66(1), pp. 35-65.

Mauro, P. (1995), "Corruption and Growth," Quarterly Journal of Economics, Vol. 110(3), pp. 681-712.

McInnish, T. H. and R. A. Wood (1992), "An Analysis of Intraday Patterns in Bid/Ask Spreads for NYSE Stocks," The Journal of Finance, Vol. 47(2), pp. $753-764$.

McLeod, C. (2013), "N. Korea Crisis isn't just Business as Usual," USA Today, April 15.

Milgrom, P., and N. Stoke (1982), "Information, Trade and Common Knowledge," Journal of Economic Theory, Vol. 26(1), pp. 17-27.

Nam, S. (2002), "The North-South Korean Relation and Country Risk: The Impact of North-South Korean Relation on Stock Market Index," The Korean Political Science Association.

Petersen, M. A. (2009), "Estimating Standard Errors in Finance Panel Data Sets: Comparing Approaches," Review of Financial Studies, Vol. 22, pp. 435-480.

Poteshman, A. M. (2006), "Unusual Option Market Activity and the Terrorist Attacks of September 11, 2001," The Journal of Business, Vol. 79(4), pp. 1703-1726.

Rachman, G. (2014), "Davos Leaders: Shinzo Abe on WW I parallels, economics and women at work," Financial Times, January 22.

Rigobon, R. and B. Sack (2005), "The Effects of War Risk on US Financial Markets," Journal of Banking \& Finance, Vol. 29, pp. 1769-1789.

Surowiecki, J. (2004), “The Wisdom of Crowds," New York: Doubleday.

"South Korea's Prosperity Defense," (2010), The Wall Street Journal, November 26.

UPI (2013), "White House: N. Korea already has nuclear weapon, Iran doesn't," September 24. 
Wallace, J. L., R. G. Hartley, G. Bowman, A. Coburn, and S. Ruffle (2013), “Geopolitical Conflict," University of Cambridge working paper.

Wiesenthal, J. (2014), "Ian Bremmer Explains What's Really Going On Between China and Japan and the One Issue No One is Talking About," Business Insider, January, 24.

Wolfers, J. and E. Zitzewitz (2009), "Using Markets to Inform Policy: The Case of the Iraq War," Economica, Vol. 76, pp. 225-250.

Zussman, A. and N. Zussman (2006), "Assassinations: Evaluating the Effectiveness of an Israeli Counterterrorism Policy Using Stock Market Data," Journal of Economic Perspectives, Vol. 20, pp. 193-206.

Zussman, A., N. Zussman, and M. O. Nielsen (2008), "Asset Market Perspectives on the Israeli-Palestinian Conflict," Economica, Vol. 75, pp. 84-115. 


\section{Appendix A. Comparing levels of attention to NK and to SK using Google Search Volume Index}

Attention level th NK vs. SK : comparison using Google Search Volume Index

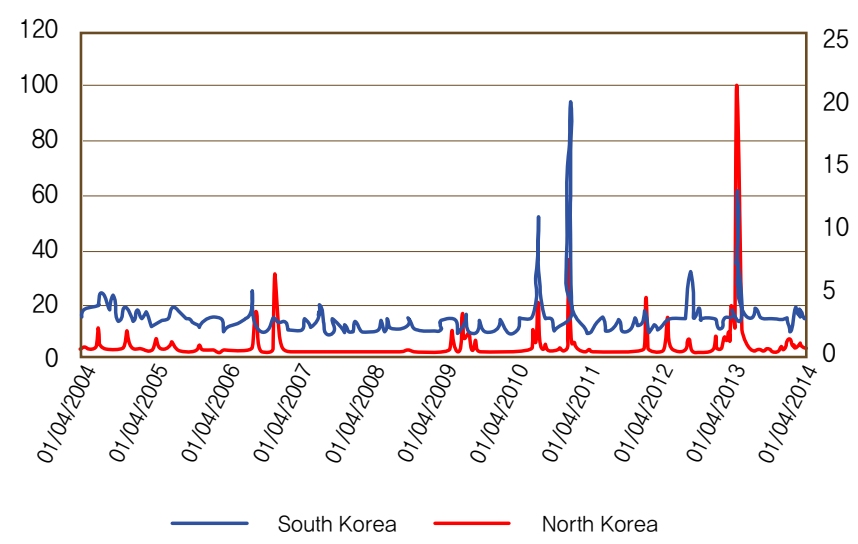

\section{Appendix B. Map of East Asia (Source: Google Maps)}

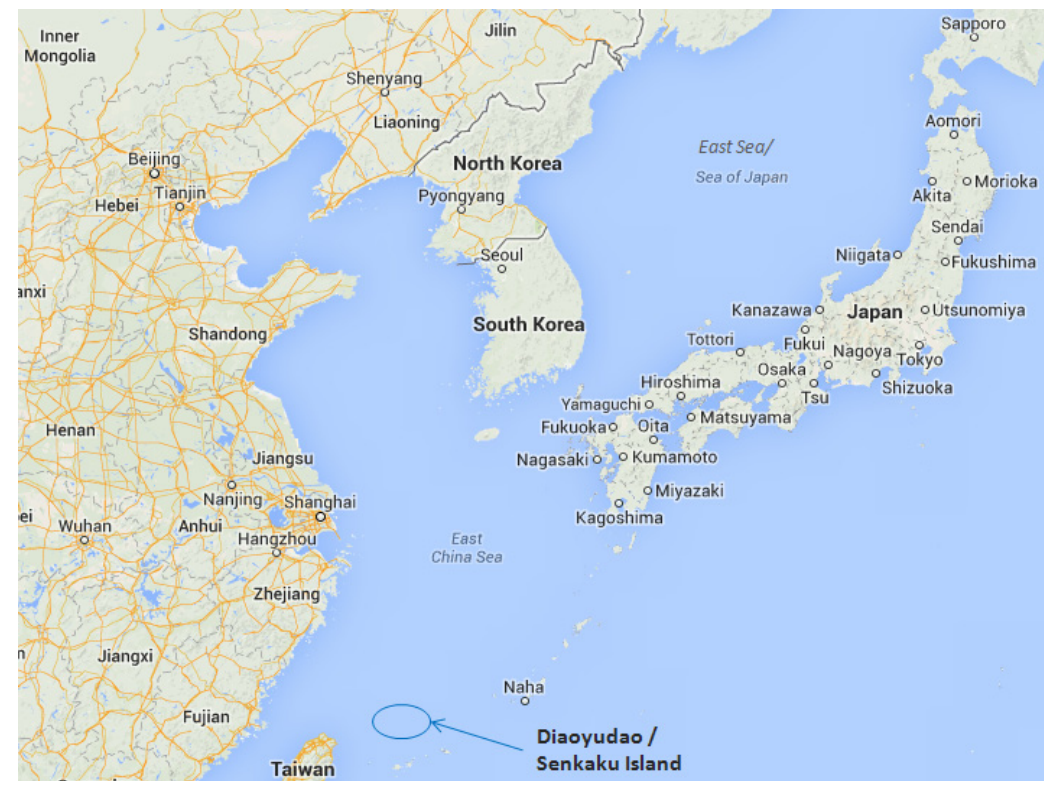




\section{Appendix C. List of "Economic cooperation" and "Defense" stocks}

\begin{tabular}{|c|c|c|}
\hline \multicolumn{2}{|c|}{ Name of Econ Coop Stocks } & Name of Defense Stocks \\
\hline ACEBED & KOREA ELECTRIC POWER CORPORATION & ACE TECHNOLOGIES CORP. \\
\hline ASIA AGRICULTURAL MACHINERY & $\begin{array}{l}\text { KOREA ELECTRIC TERMINAL } \\
\text { CO.,LTD }\end{array}$ & $\begin{array}{l}\text { DAEWOO SHIPBUILDING \& MARINE } \\
\text { ENGINEERING }\end{array}$ \\
\hline BNB SUNGWON CO., LTD. & KT & DEAYANG \\
\hline BOSUNG POWER & KUNNG NONG & DMS \\
\hline CHEIL INDUSTRIES INC & KWANGMYUNG ELECTRIC & DOOSAN INFRACORE \\
\hline CHERYONG & KYEONGWON INDUSTRY INC & EM KOREA \\
\hline CHERYONG ELECTRIC & LG INTERNATIONAL & FIRSTEC \\
\hline $\mathrm{CHOBI}$ & LOTTE CONFECTIONERY CO. ,LTD & FORMETAL \\
\hline CN PLUS & LOTTE TOUR & HANIL FORGING \\
\hline DAELIM & LS INDUSTRIAL SYSTEMS & HANJIN HEAVY INDUSTRIES \\
\hline DAEWON CABLE & MANIKER CO.,LTD & $\begin{array}{l}\text { HANJIN HEAVY INDUSTRIES \& } \\
\text { CONSTRUCTION HOLDINGS }\end{array}$ \\
\hline DAEWOO INTERNATIONAL CORPORATION & MIJU STEEL MFG.CO.,LTD. & HANWHA \\
\hline DONG YANG STEEL PIPE & NAMHAE CHEMICAL & HANYANG ENG CO.,LTD \\
\hline DONGBU CNI & NAMKWANG & HRS \\
\hline DONGBU HITEK & NK CO.,LTD. & HUNEED \\
\hline DS STEEL & PAN-PACIFIC CO.,LTD & HYUNDAI HEAVY INDUSTRIES \\
\hline EHWA TECHNOLOGIES INFORMATION & ROMANSON & HYUNDAI-WIA \\
\hline EMERSON PACIFIC & SAMBU & KANGLIM \\
\hline GAON CABLE CO.,LTD & SAMCHULY BICYCLE & KIA \\
\hline GEUMHWA PSC & SAMSUNG C\&T & KISAN TELECOM \\
\hline GOODPEOPLE & SAMSUNG FINE CHEMICALS & KOREA AEROSPACE INDUSTRIES \\
\hline GREENCROSS & SEMYUNG ELECTRONIC & KOREAN AIR LINES CO.,LTD \\
\hline GS CONSTRUCTION & SEONDO ELECTRIC & LUMENS \\
\hline HAEIN & SHINWON & MDSTECHNOLOGYCO. ,LTD. \\
\hline HALIM & SUNGBO CHEMICAL & PEOUNGHWA IND \\
\hline HANSSEM CO.,LTD. & TAEKWANG INDUSTRIAL CO., LTD & POONGSAN CORPORATION \\
\hline HISTEEL CO., LTD & TONG YANG MOOLSAN & POONGSAN HOLDINGS \\
\hline HUNDAI STEEL COMPANY & TONGYANG & S\&T DYNAMICS \\
\hline HYOSUNG & VITZROSYS & S\&T HOLDINGS \\
\hline HYUNDAI CORPORATION & VITZROTECH & S\&T MOTIV \\
\hline HYUNDAI ELEVATOR & WOOWON INFRA & SAMSUNG HEAVY INDUSTRIES \\
\hline HYUNDAI ENGINEERING \& CONSTRUCTION & & SAMSUNG TECHWIN \\
\hline $\begin{array}{l}\text { HYUNDAI MERCHANT MARINE } \\
\text { COMPANY LIMITED }\end{array}$ & & SAMYUNG ENC \\
\hline ILJIN ELECTRIC & & SATRECINITIATIVECO. , LTD. \\
\hline ILSHIN STONE & & SPECO \\
\hline IN THE F & & STX ENGINE \\
\hline INZI CONTROLS CO.,LTD & & THEALLMEDIBIO \\
\hline JAEYOUNG SOLUTEC & & VICTEC \\
\hline JAHWA ELECTRONICS CO.,LTD & & WELCRON \\
\hline KOLON CORPORATION & & WITHUS CO., LTD. \\
\hline KOREA ELECTRIC POWER CORPORATION & & YTN \\
\hline
\end{tabular}

Notes: The first panel lists "Economic coop stocks," meaning stocks of companies involved in economic cooperation with NK. We construct our list by combining the lists in Ahn, Chay, and Jeon (2010) and those used in Shinhan Bank and Korea Investment Securities Co. The second panel lists "Defense stocks," meaning stocks of companies produce defense industry products, such as tanks and heavy machinery. 


\section{Technical Appendix}

\section{Microstructure event study}

In this section, we examine how quickly the events are priced and who trades first by using microstructure data. Busse and Green (2002) document that it takes about seven minutes for a negative earnings surprise to be priced in the US market. We understand that the SK stock market may be less efficient than that of the US, and the kind of news concerned is also different. It seems, therefore, worth investigating how fast investors respond to geopolitically negative news such as of nuclear weapons testing, because the events may give profound information about the fundamentals of the business environment of companies listed in Korea. Again, we focus on NK's testing of nukes/LRMs and acts of military aggression.

We first collect the time stamps of the first media reporting of the events, and the time stamps of the event occurrences. Among the ten events of Nuke/LRM testing and 13 events of military aggression, we are able to find time stamps for eight and eleven events respectively. Among these, 12 took place during trading hours (five Nuke/LRM tests and seven acts of military aggression). Based on the millisecond trade data of the SK stock markets, we construct the minute-by-minute price data using the price closest to the end of the minute as the price at the end of the minute. When there was no trade in a given minute, we take the previous minute's price as that of the current minute in a recursive manner. Since this is a very short horizon event study, we use the raw return over each one-minute interval. Panel A of Figure 12 shows the event study surrounding the minute of event occurrence, irrespective of the first minute of reporting. We find that it takes about seven minutes for the market to reflect the geopolitical news in the price, a speed comparable to the finding in Busse and Green (2002). What is interesting is that the price starts to move downward even four minutes before the actual testing. For NK acts of military aggression, we find a significant negative spike at the minute of their initiation, with some noisy drift over the subsequent minutes. As time passes the price drifts back to the original level of the spike, with some noise. It is plausible that some investors who have the information of the breakout of military conflict trade immediately, while the others trade belatedly or do not even care about the event. Since we find 
statistically significant price movements for nuclear testing and military aggression, we further analyze the trading volumes by the minute for these two groups of events.

For every minute of the event date, we estimate the average trading volume for each stock. Then, for the event window of $[-15,15]$ minutes centered at the minute of event occurrence, we compute the abnormal trading volume of each stock by dividing the trading volume of each minute by the average trading volume. We then take the cross-sectional average. The results are shown in Panel B of Figure 12, which indicates that investors trade $100 \%$ more than average at the minute of occurrence of an act of military aggression. In contrast, the abnormal trading volume gradually increases after the minute of nuclear/LRM testing, peaking at the third minute after occurrence. It might be that, for the surprise military attacks by NK,

Figure TA1: Microstructure event study of geopolitical event news

Panel A. Stock price responses to different kinds of aggression by NK in $[-15,15]$ minute interval surrounding event time stamp

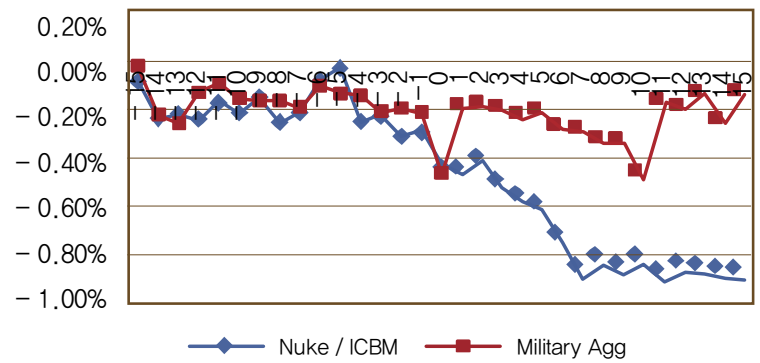

Panel B. Trading volumes relative to daily average $[-15,15]$ minutes surrounding acts of NK military aggression vs. Nuke/LRM testing

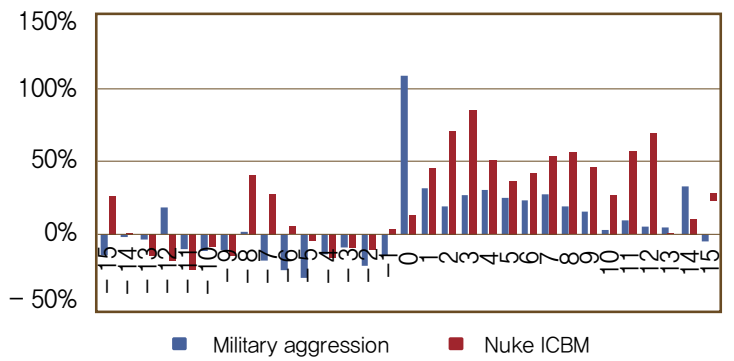

Notes: Relative to daily average $[-15,15]$ minute interval surrounding acts of NK military aggression vs. Nuke/LRM testing 
the SK investors trading closer to the places of conflict have more rapid access to the news and their perceptions of risk are much greater than those of investors trading at branches far from the places of military conflict. In contrast, because NK's nuclear testing takes place in its own territory, it takes about three minutes for the information to be diffused to investors and for them to trade significantly more.

\section{Who trades more at the minute of military aggression?}

In this subsection we use multiple regressions to better understand who trades at the very minute of the outbreak of military aggression. In an ideal world, where information is available to all market participants simultaneously, the geographical proximity of traders to the place of outbreak should not matter. Empirically speaking, working with SK data may bias us against finding the result because the sheer size of its land mass is only one percent that of the US. However, one interesting feature of the Korean microstructure data is that it identifies the local branch of the brokerage house at which each order originates. Given that almost all local branches carry the names of the towns in which they operate, we hand collect the latitudes and longitudes of more than 3,500 local branches of the brokerage houses in Korea through Google Maps or Naver Maps, as in Kim and Jung (2014). We in addition collect the coordinates of the locations of the military conflicts. We then compute the distance between a local branch and the area of conflict as follows:

Distance $=$

$\frac{6371 \pi}{180} \sqrt{(\text { Latitude diff })^{2}+\cos \left(\frac{\text { Lat } 1+\text { Lat } 2}{2} \times \frac{\pi}{180}\right)(\text { Longitude diff })^{2}}$

We next regress the trading volume of the branch at the minute of event occurrence for each stock on the geographical distance and other controls, such as firm characteristics. Because we conjecture that it is individual investors who trade more sensitively to the outbreak of military conflict, we of course do the studies for the individual investor sample and the institutional investor sample separately for a contrast. Also, since the Korean microstructure data identifies whether a trade is initiated by 
a buy or a sell order, we use the sell and buy volumes and order imbalances (buysell) separately. If the buy and sell volumes increase equally then we will not be able to detect any increase in order imbalance even though the trading volume goes up. In addition, we exclude the local branches in the Seoul metropolitan area, which are shown as the first three rows in Appendix TA1. Nearly two-thirds of the local branches of brokerage houses are located in this area, which happens to be close to $\mathrm{NK}$, and thus if we include this area, one might argue that the result is simply a spurious correlation caused by the fact that more trading volume comes from the densely populated area.

Our empirical model for analyzing the trading volume at the minute of event occurrence is as follows:

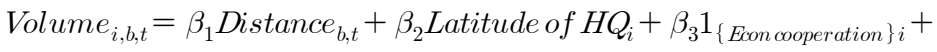

$$
\begin{aligned}
& \beta_{4} 1_{\{\text {Defense Stock }\}}+\beta_{5} \text { foreign ownership }_{i, t}+\beta_{6} \# \text { shares outstanding }{ }_{i, t}+ \\
& \beta_{7} 1_{\text {yr daily volatility }}{ }_{i, t}+\beta_{8} \ln (\text { total assets })_{i, t}+\beta_{9} R O A_{i, t}+\beta_{10} \text { BEME }_{i, t}+ \\
& \beta_{11} \text { leverage }_{i, t}+\text { Industry } F E_{i, t}+\epsilon_{i, t} \text {, }
\end{aligned}
$$

where $\mathrm{i}$ is a subscript of the stock, b a subscript of the branch of the brokerage house, and $\mathrm{t}$ a subscript of the event. BEME is the book-to-market ratio, and the leverage ratio is the book value of interest-bearing debt divided by total assets. Table 4 shows the results.

First and foremost, we find strong evidence that individual investors who place orders at branches located closer to the place of a military conflict trade significantly more at the minute of conflict outbreak. Individual and institutional investors do not seem to consider the distances of the headquarters of the firms from NK. Individual investors' selling volume is significantly less for defense stocks. Individual investors sell the stocks of small firms more. Given that acts of military aggression only generate short run overreaction and reversal, these results seem to explain that the overreactions are primarily driven by individual investors living closer to the area of conflict. 


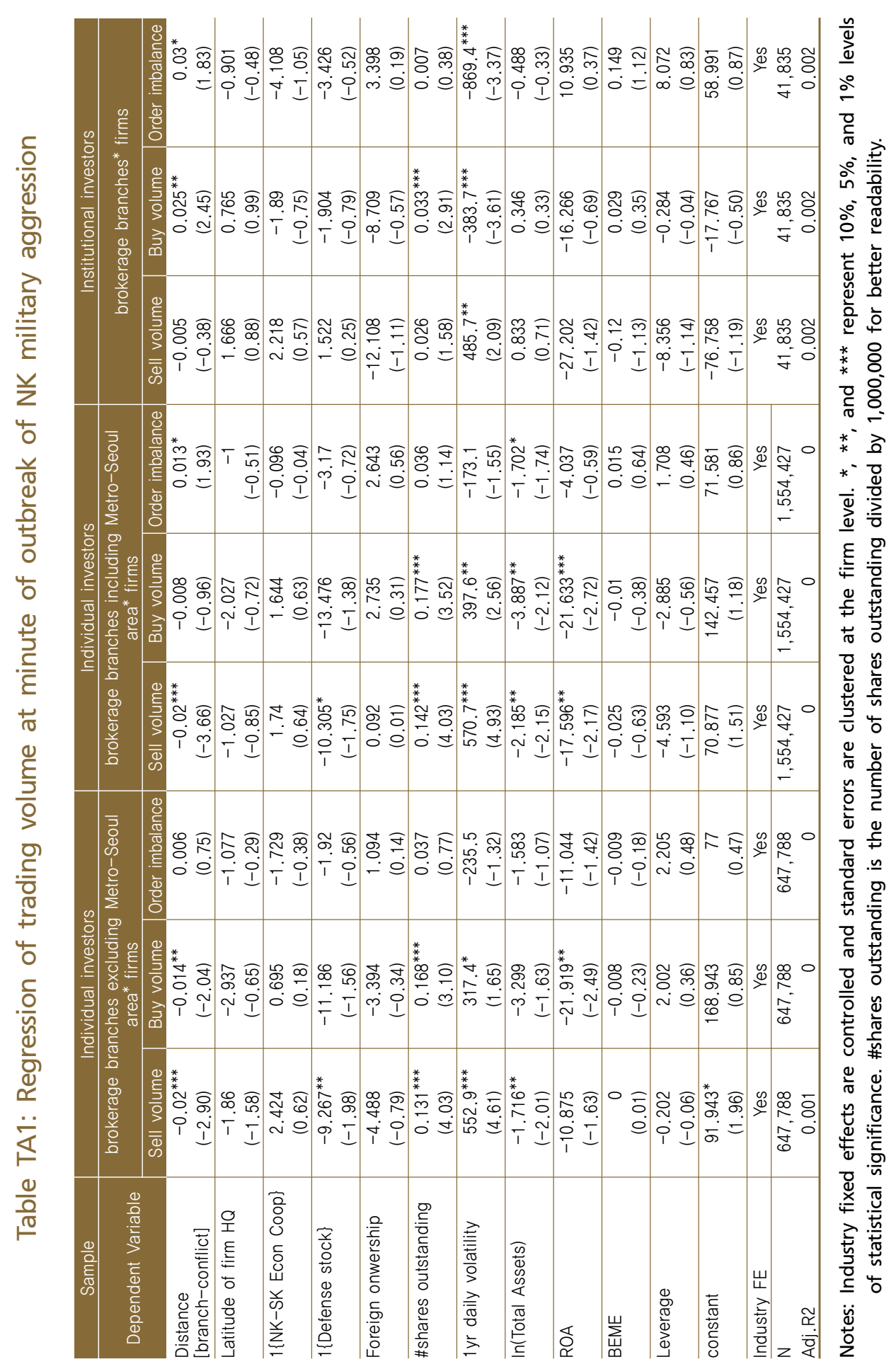


Even though the acts of military aggression by NK, such as shelling certain small areas of SK, may not imply NK's intension of igniting an all-out war against SK, witnessing the fatal military attacks in neighboring towns would have strong effects on the risk perceptions of individual investors, so that they would try to liquidate their financial assets or reallocate their investments to safer assets. At the same time, some investors might interpret such an attack as a chance to buy a security at a cheaper price by providing liquidity, because of the perception that the geopolitical risk of the country as a whole does not change. This is precisely what we find. The individual investors living closer to the areas of military conflict are the ones that trade more. If the investors in the financial markets were exposed to the news of military attack at the same time without any time delay, we would not be able to see such significant differences. Our microstructure data of SK enables us to find that the geographical proximity to the related information does matter. 


\section{Appendix TA1: Concentration of brokerage branches in Seoul metropolitan area}

\begin{tabular}{c|c|c|c}
\hline Area code & Area name & Frequency & Percentage \\
\hline 2 & Seoul & 1727 & 47.04 \\
31 & Gyeonggi-do & 529 & 14.41 \\
32 & Incheon & 86 & 2.34 \\
\hline 51 & Busan & 254 & 6.92 \\
53 & Daegoo & 162 & 4.41 \\
55 & Gyeongsangnam-do & 119 & 3.24 \\
62 & Kwangjoo & 118 & 3.21 \\
63 & Jeollabook-do & 97 & 2.64 \\
42 & Daejeon & 96 & 2.62 \\
54 & Gyeongsangbook-do & 89 & 2.42 \\
61 & Jeollanam-do & 74 & 2.02 \\
52 & Ulsan & 73 & 1.99 \\
33 & Kangwondo & 60 & 1.96 \\
43 & Choongcheongbook-do & 58 & 1.63 \\
41 & Choongcheongnam-do & 26 & 1.58 \\
64 & Jeju & 31 & 0.71 \\
\hline 999 & Undetermined & 0.84 \\
\hline
\end{tabular}




\section{$<$ Abstract in Korean $>$}

Young Han (Andy) KIM*, Hosung JUNG**

과거 10 여년간 북한이 핵실험, 장거리 미사일 발사 등의 도발을 감행함으로써 우리나라의 지정학적 위험이 크게 높아졌으며, 이는 우리나라 금융시장에도 상당한 영향을 미쳤을 것으로 판단된다. 본고에서는 이러한 북한의 도발에 따른 지정학적 위험의 증가가 우리나라 주식시장에 어떠한 영향을 미쳤는지에 대하여 1999년부터 2012년까지의 주식시장 실거래데이터를 이용하여 실증분석 하였다.

분석결과는 다음과 같다. 북한의 핵무기 실험 및 장거리 미사일 발사는 평균적으로 주가수익률을 $1.6 \%$ 하락시켰다. 또한 사건 2 3일 전부터 호가스프레드가 증가하는 등 시장유동성도 감소한 것으로 나타났다. 아울러 사건 수 일전부터 공매도(short-selling)가 증가하는 등 투자자간에 북한관련 정보의 비대칭성이 크다는 점을 확인하였다. 본고의 분석결과는 북한관련 지정학적 위험이 금융 시장 불안정에 미치는 영향에 대한 이해를 높임으로써 관련 정책수립시 참고 자료로 활용될 것으로 기대된다.

* Nanyang Business School, NTU, Singapore

** Economic Research Institute, the Bank of Korea 